AperTO - Archivio Istituzionale Open Access dell'Università di Torino

\title{
Cherubim: (Re)presenting Transcendence
}

\section{This is the author's manuscript}

Original Citation:

Availability:

This version is available http://hdl.handle.net/2318/142291

since

Published version:

DOI: $10.1086 / 674426$

Terms of use:

Open Access

Anyone can freely access the full text of works made available as "Open Access". Works made available under a Creative Commons license can be used according to the terms and conditions of said license. Use of all other works requires consent of the right holder (author or publisher) if not exempted from copyright protection by the applicable law. 


\section{CHICAGO JOURNALS}

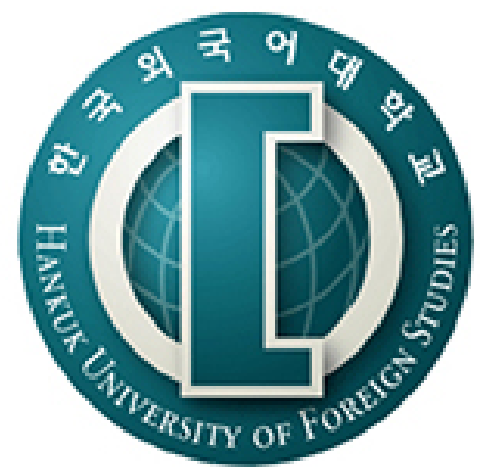

Cherubim: (Re)presenting Transcendence

Author(s): Ugo Volli

Source: Signs and Society, Vol. 2, No. S1 (Supplement 2014), pp. S23-S48

Published by: The University of Chicago Press on behalf of the Semiosis Research Center at Hankuk University of Foreign Studies and Brandeis University

Stable URL: http://www.jstor.org/stable/10.1086/674426

Accessed: $28 / 02 / 2014$ 03:30

Your use of the JSTOR archive indicates your acceptance of the Terms \& Conditions of Use, available at http://www.jstor.org/page/info/about/policies/terms.jsp

JSTOR is a not-for-profit service that helps scholars, researchers, and students discover, use, and build upon a wide range of content in a trusted digital archive. We use information technology and tools to increase productivity and facilitate new forms of scholarship. For more information about JSTOR, please contact support@jstor.org. 


\title{
Cherubim: $(\mathrm{Re})$ presenting Transcendence
}

Ugo Volli, Università di Torino

\begin{abstract}
There is a very general problem of representing transcendence in different culture: how to make present what is by definition beyond human experience. Many cultures forbid it, other as the Christian one allow representations of some divine presence in the world. Jewish tradition is in general strongly anti-iconic and especially forbids any representation of divinity. But in the most sacred place of Judaism, the Holy of Holies, the book of Exodus prescribes the presence of two statues of "cherubim," which are identified with a class of angels. This article follows the motif of cherubim in the biblical and postbiblical literature, showing that they are not representations of transcendence, but rather indirect representatives of the Jewish people as they provide a device for realizing the state of the people and its relation with the divinity, a metapragmatic sign for the paradoxical presence of the transcendence in the midst of it.
\end{abstract}

$\mathrm{T}$ here is an obvious oxymoronic tension in every religious representation. By definition, it has indeed to re-present (whose core etymological meaning entails making something present-again), not a simple daily life object but a transcendent one, ${ }^{1}$ that is, something that is not (only) present in the world, not really included in it, whose most important essence is beyond human experience. The specific problem for every representative practice defining itself as religious is how to tackle this tension: how to make (again) present something that by definition is not (empirically) present. I will explore a very peculiar case, that of cherubim in the Jewish biblical tradition, whose main manifestation was a double golden statue kept in the holy of holies of the Tabernacle, as the biblical book of Exodus describes it. This is just the salient point in a thousand-year-old story of descriptions, representations, discussions of these entities: a recurrent iconological motif that could very well

1. A definition of the transcendent is obviously beyond the limits of this article. I refer to Kant's "Introduction to the Transcendental Dialectic," \$1, in his Critique of Pure Reason, and to Lévinas 1984, 1995.

Signs and Society, vol. 2, no. S1 (Supplement 2014). () 2014 Semiosis Research Center at Hankuk University of Foreign Studies. All rights reserved. 2326-4489/2014/02S1-0002\$10.00 
be a Warburgian atlas item (Warburg 2003). Of course, it is not the remote origins of this motif or the hypothetical reasons of its introduction in the biblical text that interests semiotic studies, but rather its long presence and the different textual and representational images the motif was able to engender, with the problems resulting from its reception in a strongly iconoclastic tradition.

Before focusing on cherubim, a general discussion about the difficulty of representing transcendence is necessary. We can easily distinguish, in the wide geographical and historical variety of cultures, two main opposed solutions and a range of intermediate compromises for the problem I have summarized at the beginning: if and how it is possible make present transcendence in representations.

The former one is based on the idea that transcendence, in order to be perceived by human beings and act on them, aside from being worshiped by them (which is the core stance of religion), should also be somehow immanent in the human world, maybe through some sort of agent or sign or appearance. It is this immanence, agent, or appearance that can (and should) be represented. This first position corresponds to the very central issue of Christian faith insofar as (transcendent) God is believed to have made himself an (immanent) man in order to save humankind. Although time and again many streams of Christianity took the position of some kind of iconoclasm in order to protect divine transcendence, the main Christian tradition deduced exactly from Jesus's Incarnation the possibility of using images for representing divinity, because both are examples of divine presence in the world (Kurulyk 1991). This parallelism was stressed by the Middle Ages rule that every sacred image should be linked to a relic (Appadurai 1986). Actually, the likeness of contact and perception for the transmission of sacredness was theorized by Iohannes Damascenus ("Pros tous diaballontas tas aigias eikonas"). ${ }^{2}$

But this strategy of authorizing representations of transcendence through its immanent surface is not limited to the complex Christian theology of the Incarnation. Greek and (as far as I know) Indian gods are transcendent: their deep nature is not part of this world, their real place is outside it, and their life is too wide and different from the human experience to be conceivable (and therefore graspable) by mortal human beings. Usually they are not even visible by themselves. But they are representable and in fact richly represented, precisely because they can take on visibility, as they take different shapes in order

2. Kurulyk 1991, 37; an English translation can be found at http://www.ccel.org/ccel/damascus/icons.toc .html; cf. Geary 1986, 175-76. On this problem, see Russo (1997); Belting (2005); Bettetini (2006). A semiotic analysis of this very important point can be found in Volli (1997). 
to communicate with humans or enjoy of them. It is useful in this regard to consider a fundamental distinction proposed by Karol Kereny $(1962,168)$ that shows that our concept of divine image should be divided into three distinct notions, in order to adhere to Greek language (and thought): "Greek eidolon is an image that consists solely of a surface without depth. Eidola can be described as mirror images that have acquired an independent existence after you have mirrored those that are already extinct . . . eidola were the sine corpore formae. . . . Here we can speak of a ghostly form. Eidola were created by the gods to deceive mortals." ${ }^{3}$ As Dorfles also explains $(1988,14)$, Greek eidola were the real "emanations" or Ersaetze of the authentic divinity that could replace them in many aspects; in particular, they could be used by gods in order to show themselves but not by others as possible signs of the gods. Thus, eidola were not the idols and the images in the temples, which were called agalmata: objects of worship, true signs of the divine, that is, what we might call today more easily idols, built according to a semiotic principle of similarity. The third term is eikon: "Eikon is, strictly speaking, an historical image and therefore is seldom used for the statues of the gods. We find explicitly said that the agalmata are fit to the gods and the Eikones to men. Eikones, as images for worship, were, according to the content of the Greek word, adopted by Christianity, because Christian icons want to be historical and not merely symbolic" (Kereny 1962, 168).

In short, agalmata 'representations' were made possible because gods had appearances, or eidola 'presentations', as Christian eikona were possible because of the Incarnation. Representation of transcendence is a second degree relation, realized through immanence or appearance, an actual re-presentation. The believers are not always aware of this indirect relation, but this complex metaphysical link is the formal ground of their use of images, and it became a sort of obviousness in Western culture: the invisible can be made visible through images of its immanence, or metaphorical signs, different ways of humanizing it.

\section{Images Interdict}

The other, opposite, solution is denying representation, forbidding it. As Goody (1997) explains, this is a very diffused cultural stance. One cannot

3. Of course, Greek culture and theology are far too complex and articulated for this short summary to be completely correct. I am merely referring to a very general position in order to make a comparative point. Cf. Veyne 1983. 
represent divine things, because representing divinity entails grasping it, pretending to understand it, and in some way obtaining a power on it. More, it means attributing a divine quality in something made by man, as states Isaiah 44:12-17 (and many parallel passages):

The man shapes iron into a cutting tool and does his work over the coals, fashioning it with hammers and working it with his strong arm. He also gets hungry and his strength fails; he drinks no water and becomes weary. Another shapes wood, he extends a measuring line; he outlines it with red chalk. He works it with planes and outlines it with a compass, and makes it like the form of a man, like the beauty of man, so that it may sit in a house. Surely he cuts cedars for himself, and takes a cypress or an oak and raises it for himself among the trees of the forest. He plants a fir, and the rain makes it grow. Then it becomes something for a man to burn, so he takes one of them and warms himself; he also makes a fire to bake bread. He also makes a god and worships it; he makes it a graven image and falls down before it. Half of it he burns in the fire; over this half he eats meat as he roasts a roast and is satisfied. He also warms himself and says, "Aha! I am warm, I have seen the fire." But the rest of it he makes into a god, his graven image. He falls down before it and worships; he also prays to it and says, "Deliver me, for you are my god."

Not only is representation impossible, but it is also forbidden. Divinity will take revenge for such an affront. The first reason of this interdict is to be sought in the consequences of such an absurd gesture as crafting an idol, making something which is, in some respect, a God: for the believer it means being deluded without any benefit. Even worse: for God this is a betrayal and a humiliation: being supplanted by a thing, maybe even being supposed to look like him (which entails the reverse case: if there is a thing looking like him, he is also in a sense like a thing). ${ }^{4}$

In some cultures there are more general interdicts about representation: not only can $(a)$ divinity not be represented, but also it is forbidden for (b) human beings, $(c)$ animals, and even $(d)$ such natural categories as plants, stars, and landscapes. Some Christian iconoclastic position share interdiction $a$; Jewish and Muslim traditions obey $a$ and $b$; some African cultures studied by Goody respect $c$, and in some cases there is even an additional prohibition: 
(e) narrations about transcendent reality. Here, too, the reason is a theological one: because only God creates, daring to represent (i.e., to imitate) any human, animal, or otherwise natural form means emulating God's operations, usurping his prerogatives. For this reason, in Europe actors were longtime despised by the church.

Apart some very rare and isolated cases of $e$ kind of interdictions, in general, interdictions from $a$ to $c$ go together. If divine images are forbidden, natural ones are also often unwelcome. If statues and portraits are permitted, subjects are seldom limited to natural ones; often, as in the European Middle Ages, only sacred images are considered deserving of representation. It could seem, therefore, that the main border separates verbal language, which always seems permitted in Mediterranean cultures, from the (often problematic) visual expression. There are a number of clues in different cultures that seem to lead in the this direction, a sort of privilege of hearing over sight. For instance, in the Jewish Torah, ${ }^{5}$ mainly in the book of Deuteronomy, one could note some evident theological distrust for the experience of divine revelation through the sense of sight. The main passage is Deuteronomy 4:12-19:

And the LORD spoke unto you out of the midst of the fire; ye heard the voice of words, but ye saw no form; only a voice. And He declared unto you His covenant, which He commanded you to perform, even the ten words; and He wrote them upon two tables of stone. And the LORD commanded me at that time to teach you statutes and ordinances, that ye might do them in the land whither ye go over to possess it. Take ye therefore good heed unto yourselves-for ye saw no manner of form on the day that the LORD spoke unto you in Horeb out of the midst of the fire-lest ye deal corruptly, and make you a graven image, even the form of any figure, the likeness of male or female, the likeness of any beast that is on the earth, the likeness of any winged fowl that flieth in the heaven, the likeness of anything that creepeth on the ground, the

5. By "Torah" in this article I mean the Jewish canon, as defined by the Jewish living tradition: primarily the five books of Moses but also the others books of the Jewish Bible and their commentary and developments (Mishnah, Talmud, Midrash, etc.). I am not interested here in the very complex compositional process of this wide complex of texts, nor do I find relevant for my project trying to know or rather to imagine what the texts were like in their first formulations, why and by whom they were produced, or with what intentions they were worded. All these problems belong to the so-called high philology in Bible studies, while this article seeks to address a semiotic problem. From a semiotic point of view, the meaning of a text is not what the author meant composing it, but what its regular audience can understand of it, using its codes. Because the living Jewish tradition understands itself as Torah (also, what will be affirmed in the future by a "trained student" has to be considered as min Sinai 'heavenly given', asserted by a very well-known Talmudic sentence), I call the object of my research "self-understanding" of the Torah and analyze the texts as they are. 
likeness of any fish that is in the water under the earth; and lest thou lift up thine eyes unto heaven, and when thou seest the sun and the moon and the stars, even all the host of heaven, thou be drawn away and worship them, and serve them, which the LORD thy God hath allotted unto all the peoples under the whole heaven.

The logic here is that seeing any "form" (temunah) in the process of God's revelation seems to be more or less the same or could be the cause of "making graven images" (pesel) of living being or to make "the form of any figure" (temunah col samel) in resemblance (tabenit) of living being, which-says the text-leads directly to idolatry and worshiping stars, then to sin and "abomination." Pesel and temunah are literally what is forbidden in the second "word" of the Decalogue (Exod. 20:3, Deut. 5:8) and also this explanation of what cannot be represented is a sort of extended comment on that passage. What is new here is the link from any visual perception of divine manifestation (temunah in the verse 12 , which can be understood as the same phenomenon as the Greek eidolon discussed above) with the pesel or the temunah kol samel in the verse 16 , that is, type $b$ representations, and from that to the idolatry of natural (i.e., not transcendent) thing as stars in verse 19. The same link between sign-like presence and representation that authorizes representations and polytheism in Greek society forbids visual theophany in the Jewish tradition.

This link can be better understood if we reflect on the ambiguity of the word "representation," which, apart from the political or juridical meaning of "action of speaking or acting on behalf of someone or the state of being so represented" means both "an artistic likeness or image," "a picture, model, or other depiction of someone or something," and "a mental state or concept regarded as corresponding to a thing perceived." For the Oxford English Dictionary this last meaning depends on "some theories of perception," but in fact the use of some concept as "mental representation" is largely diffused. Jacques Le Goff, for instance, writes $(1985,6)$, “This very generic word incorporates every possible mental translation of a perceived external reality. Representation is linked to abstraction process. The representation of a cathedral is the very idea of a cathedral."

This double-sided representation (material or mental, made or perceived) recalls a similar development of the related notion of "image," which, according to Merriam-Webster's, is both "a reproduction or imitation of the form of a person or thing" (human-made object) and "the optical counterpart of an object” (subjective impressions more or less technically manipulated) and hence 
in a metaphoric way "a mental picture or impression of something." What is made and what is perceived are not opposite by nature, but share the same ground - the evidence of visibility.

The theological or even moral distrust for theophanic representations in the Torah is paradoxically explained by the gnoseological high esteem of sight in the Hebrew texts: ${ }^{6}$ what is seen is, in general, regarded as true even if very strange. The same happens in our culture, where seeing something is far more convincing evidence than "hearing" it. In all of the Jewish Bible, laws are told, but miracles are seen, not heard. ${ }^{7}$ This is the case for the burning bush, of the ram in Isaac's binding, of the plagues in Egypt, and even of prophetic revelations as in the beginning of the book of Ezekiel. In the story of Babel, even the Lord wants to see things in order to judge them. ${ }^{8}$ The trustfulness and the ability of "grasping" the object of sight are the paradoxical reason why one "cannot see God and live," as Moses is told when he asks to see God "face to face" (Exod. 33:18-20) and instead receives in Exodus 34:4-6 the verbal proclamation of thirteen divine "attributes" (middot, 'measures').

\section{Mimesis}

In fact the opposition goes between diegesis and mimesis, in the sense first proposed by Plato (Republic 3.392d-394c). ${ }^{9}$ Thus visual knowledge is naturally perceived as mimetic; both produced and received representations are thought to be working similarly, or rather, the objective representations are understood as devices made in order to produce mental, mimetic representations - to "imitate" things, in Plato's language. The root of his criticism is the following:

6. As noted above, in the language of Bible studies there is the habit of distinguishing and even opposing what is "Hebrew" and what is "Jewish," where the first term should characterize an older stage (for some older than Babylonian exile, for others older than the separation of Christianity and "Judaism," for still others older than the Roman destruction of the Jerusalem Temple, $70 \mathrm{CE}$ ). In fact, this distinction does not correspond to the general linguistic use, which is very varying (e.g., in French, hébreux is not normally used; in Italian, ebreo is the regular use, whereas giudeo is a derogatory antisemitic usage, or a very bygone one, and so on. Also this habit does not respect the linguistic use in the Pentateuch, where ben Yisrael 'Israelite' is the regular wording, while ivri 'Hebrew' is rarely used, generally only in a context where foreigners come into question. Only once the kingdom of Solomon split into two states (the northern called after Israel and the southern after Judah) did the denomination "jehudi," hitherto only employed in reference the members of the Jehudah tribes, prevail. But all this happened well before the aforementioned a quo date. What interests me is the "Jewish tradition," the one that we know from the Mishnah, the Talmud, and other witnesses and that has continued to grow, claiming continuity with what today in some environments is called "Hebrew." The semiotic methodology forces us to consider the texts in the state in which they were transmitted to us and actually exist (apart from any obvious "low philology" emendations). Therefore hypotheses non fingo about their hypothetical "Hebrew" state.

7. Often they are named with the word ot 'sign, letter of the alphabet, flag'.

8. For a discussion of the sense of sight in Jewish tradition, see Volli, forthcoming.

9. It seems to me very meaningful that Plato uses this distinction in order to support a position very similar to our type $d$; cf. Republic 3.395b-396a. 
mimesis seems to produce its effects without anyone taking responsibility for it, by hiding the author behind the representation, which he calls "assimilation to another." Plato's famous example is taken from poetry and shows how at some point Homer becomes mimetic (and so does tragedy always):

You are aware, I suppose, that all mythology and poetry is a narration of events, either past, present, or to come? / Certainly, he replied. / And narration may be either simple narration, or imitation, or a union of the two? / . . . And this assimilation of himself to another, either by the use of voice or gesture, is the imitation of the person whose character he assumes? / Of course. / Then in this case the narrative of the poet may be said to proceed by way of imitation? / Very true. / Or, if the poet everywhere appears and never conceals himself, then again the imitation is dropped, and his poetry becomes simple narration. (Republic 3.392d)

But while there is a possibility for poetry to be diegetic and not mimetic, that is, for the poet to assume responsibility for describing the world being present to his discourse (e.g., in lyric poems), this is not possible for representative images, which always present themselves as something in the world. Let us follow Plato's analysis with the famous example of beds (Republic 10.596a-597a). There are three kinds of beds: one existing in nature, or rather in the "world of ideas" (the ideal one, made by God); one made by the craftsman by imitating God's idea; and one represented by painters, who by copying the carpenter's work in their image become imitators but three times removed from the truth. These copies are able to touch only on a small part of things as they are in reality, where a bed may appear differently from various viewpoints, looked at obliquely, directly, or differently again in a mirror. So painters, though they may appear to work like a carpenter or any other crafter, know nothing of the carpenter's craftsmanship; likewise though the better painters they are, the more faithfully their works of art will resemble the carpenter's bed-making reality; nonetheless, being imitators still they will not attain the truth (of God's creation). The same could be said of the mimetic writer (the tragic poet) or of any other kind of mimesis. Imitation is the problem here: with every passage the result gets further and further away from the truth, every simulation is a lie.

Of course I do not hold the pretense of explaining the biblical interdict on images with Platonic theories: between them are centuries as well as cultural and geographic boundaries. My point is that the Deuteronomic interdictions too should be understood as referring to semiotic modalities of representation, 
not about sensory channels. This antimimetic stance is well observed in the text: all biblical narration, even in livelier and more realistic passages, is very careful to keep distinctions between enunciation and enunciated, especially where enunciated enunciations appear in the text, for instance in dialogues, where débrayages are always well marked. All the time, the reader is put in a position of awareness, not of illusion; this stance is strengthened by the tradition of studying Torah by discussing the meaning of every single word, confronting contradictions and differences, trying to find other significations.

I would like to add one further remark to support my point about sight: the role of writing (which, if alphabetic, is a visual but not mimetic medium) in the biblical ideology. There are many places in the Bible where the activity of writing is considered, often in the form of a book (Volli 2009), and sometimes at least the clue of a self-quotation is there (e.g., Deut. 28:18, 29:20, 31:26). Also, writing is always considered in a positive way (Ouaknin [1986] 1998). We can even find the provision that the king of Israel must write for himself a copy of the Torah and read from it. ${ }^{10}$ But, of course, every reading is also a visual work, and the Torah often demands more or less explicitly to be read and studied. ${ }^{11}$ So, what arouses suspicion in the Torah is not sight in general (as one of the five senses), but a specific way of using it, namely, the representational or mimetic one as opposed to the diegetic or scriptural one.

A hint of this can be found in a rather enigmatic verse describing the reaction of the people of Israel to the proclamation of the Decalogue (Exod. 20:15). It is exactly the same occasion discussed by Deut. 4: 12 quoted above ("ye heard the voice of words, but ye saw no form; only a voice"), but this time, in the first level enunciation, it is described in slightly different form: "And all the people saw the voices and the torches, the sound of the shofar, and the smoking mountain, and the people saw and trembled; so they stood from afar." The people "saw" the voices (roim et hakolot), it is written. Often this verse is somehow normalized in translation by writing, for instance, that they "perceived the thundering" (Jewish Publication Society 1917 ed.), "saw the thundering" (King James Version), and so on. That is a naturalistic account of the revelation, clearly aimed at making it easier to accept; but in this whole episode there is no hint of a storm or thunder, only smoke, due to "the Lord descending in fire" and a "quake of the mountain" (Exod. 19:18), "the sound or

10. In biblical studies there are discussions about exactly what text the king was obliged to copy and when. This is not relevant for my point, because, at any rate, some writing was declared mandatory and thus considered as a positive activity.

11. Or rather this is the traditional interpretation of many passages. 
voice $[\mathrm{kol}]$ of the shofar" (a liturgical musical instrument made from a ram's horn) and the "voice $[\mathrm{kol}]$ of God" "answering to Moses" (Exod. 19:19). There is, therefore, no reason to add a thunderstorm; it is quite obvious that the voices "seen" by the people were God's words. A remarkable explanation is offered by one of the more authoritative commentators of Jewish tradition, the eleventhcentury Rashi:

the voices: They saw what was audible, which is impossible to see elsewhere.

the voices: Emanating from the mouth of the Almighty. Many voices, voices coming from every direction, and from the heavens, and from the earth. (Rashi ad Exod. 19:19)

"Seeing what is audible" is a strange expression that can be understood as an explanation of what reading means-as if the "voices of the Almighty" were somehow letters. At any rate, the fact of "seeing voices" where no images can be seen emphasizes a choice between semiotic modalities of theophany, even visual theophany: vision as representation (iconic modality) or reading (maybe written) words (symbolic modality). The first one is avoided, perhaps because it can produce the illusion of an immanence of the Transcendent One. This problem is sometimes circumvented by the sight of objects such as the burning bush of Exodus 3:4 or the "angels" in Genesis 18:1, 35:1-7: God's representatives, and not his representations, that for sure cannot be mistaken for him. The symbolic modality is preferred because clearly it works through the cultural filter of a double arbitrariness: there is an evident separation between reader and described "voice" and another clear distance between the "voice" and the (transcendent) entity it represents or the things it names. When you hear of something, you don't have the illusion of really knowing it. It is just a description made by a third party which you cannot say you know. Textual mediation makes the relation between humankind and transcendence less problematic, avoiding magical possession and objectification of the represented Other. As is well known, Jewish tradition adds another filter against the objectification of transcendence, even at the linguistic level, by making impossible the direct alphabetic reading of the name of God (for more details, see Volli [2012]).

\section{Cherubim}

Nevertheless, the Jewish tradition seems better placed within the moderate iconoclastic tradition than in the extreme one. This happens not only because 
its veto of representation belongs to type $b$ and not $c$ or $d$, allowing in general images of vegetable and non-animated subjects, nor only because, as we saw above, the Torah interdiction references a precise terminology of pesel (i.e., engraved or carved images vs. painted ones), which may be the reason why there are some examples of rich two-dimensional images decorating ancient synagogues (e.g., the famous third-century Dura Europos in today's Syria).

The fact is that one complex image system aimed at making transcendence present (though not literally representing it, as we will see) is not only admitted, but prescribed in the Torah. It is the tabernacle (mishkan) described in Exodus 25-27 and 35-40. Then God asks for a mobile tabernacle (mishkan) (called here also sanctuary 'mikdash'): "And let them make me a sanctuary, ${ }^{12}$ that I may dwell in their midst. ${ }^{13}$ Exactly as I show you concerning the pattern of the tabernacle, and of all its furniture, so you shall make it" (Exod. 25:8-9). The design of this tabernacle receives a very complex and detailed description in the text, with the explanation of shapes, dimensions, materials, and so on. Relevant for this paper are just some details of the most sacred part of this architecture, that is, of the Ark of the Covenant where the Decalogue tables and other sacred objects were to be kept:

They shall make an ark of acacia wood. Two cubits and a half shall be its length, a cubit and a half its breadth, and a cubit and a half its height. You shall overlay it with pure gold, inside and outside shall you overlay it, and you shall make on it a molding of gold around it. You shall cast four rings of gold for it and put them on its four feet, two rings on the one side of it, and two rings on the other side of it. You shall make poles of acacia wood and overlay them with gold. And you shall put the poles into the rings on the sides of the ark to carry the ark by them. The poles shall remain in the rings of the ark; they shall not be taken from it. And you shall put into the ark the testimony that I shall give you. You shall make a mercy seat ${ }^{14}$ of pure gold. Two cubits and a half shall be its length, and a cubit and a half its breadth. (Exod. 25:10-17)

12. From the root $k$ - $d$-sh 'holiness, separation'.

13. Often, in the Jewish exegetic tradition it is remarked that God doesn't promise to dwell in the sanctuary, but "in their midst," which is very different because the most sacred areas of the sanctuary were forbidden to people. So the sanctuary is not the "God residence," but rather a device, a focal point for sharing the divine presence among the people.

14. In the Hebrew original text, Kapporeth, literally meaning "cover," from the Jewish root $k-p-r$. Jewish translations traditionally do not use for it the expression "mercy seat," as a later Christian gloss does, but 
The ark is made of gold, which underlines the extreme importance of its content and function: it is the most important object in all Jewish liturgy. Interesting for us, as we will see, are the rules about the poles used to transport it: for instance, they must never to be detached. There is a beautiful Talmudic lecture by Lévinas ([1982] 1994) in which the philosopher interprets the prohibition to remove the poles as a sign that the Law contained in the ark should always remain unconnected to any point in time or space, ready to move at all times, and therefore universally applicable. Yet our focus here is another, a very problematic way prescribed for decorating the ark cover:

You shall make two cherubim of gold; you shall make them of hammered work, at the two ends of the mercy seat. Make one cherub at the one end, and one cherub at the other; of one piece with the mercy seat you shall make the cherubim at its two ends. The cherubim shall spread out their wings above, overshadowing the mercy seat with their wings. They shall face one to another; the faces of the cherubim shall be turned toward the mercy seat. You shall put the mercy seat on the top of the ark; and in the ark you shall put the covenant that I shall give you. There I will meet with you, and from above the mercy seat, from between the two cherubim that are on the ark of the testimony, I will speak with you about all that I will give you in commandment for the people of Israel. (Exod. 25:18-22)

We must see a huge contradiction here: ${ }^{15}$ while the Torah forbids, as we saw, any representation or likeness of living being (temunah kol samel) and particularly any graven image (pesel), in the most sacred place of Jewish liturgy (kodesh kodashim or sancta sanctorum), where God "will meet" with Moses

sometimes speak of an "atonement piece." Though kapporeth derives from kaphar, which means "cover," the literal meaning of $k-p-r$ is "to wipe out," implying that kapporeth could mean "thing of wiping out/thing of cleansing." The Hebrew term covering (כָ kapporeth) occurs twenty-seven times in the tenakh (Hebrew Bible), all of them relating to this particular item on the Ark of the Covenant.

15. This problem is hardly new, as it was addressed by some important commentators throughout Jewish Middle Ages, such as Jehudah Halevi and Abrabanel, though it never became popular in Jewish theological discussion. I quote here the summary proposed by Apple 1995: "Abarbanel asks . . 'With regard to the cherubim which $\mathrm{He}$, blessed be $\mathrm{He}$, commanded to be made upon the ark-cover, it does appear that one would be transgressing thereby the injunction in the Ten Commandments, "Thou shalt not make unto thee a graven image, nor any manner of likeness of anything that is in the heaven above or that is on the earth beneath" (Exodus 20:4). How did He command them to do that which He had warned them about?' [Abarbanel 2012] In dealing with this challenge Judah HaLevi, the philosopher, argues (Kuzari 1:97) that the Golden Calf was a clear case of defiance of the Ten Commandments because it was made without authority by people who had abandoned hope in God and sought an idolatrous alternative. The cherubim, however, were not a substitute for God, but merely a visual aid for those who needed concrete orientation in worship. . . . Abarbanel's . . . stresses that the cherubim were not objects of worship but poetical symbols standing for the duty to spend one's life poring over the Torah." As I will discuss later, another solution is possible. 
and "will speak with him"; two statues, or "hammered work," with human traits ("faces") and animal ones ("wings") must take place. ${ }^{16}$ This difficulty is underlined by another detail: the only other figurations in this whole building (and in the Jewish liturgy) are, again, cherubim: "Moreover you shall make the tabernacle with ten curtains of fine twisted linen, and blue, purple, and crimson yarns; you shall make them with cherubim skillfully worked into them" (Exod. 26:1). It is useful to specify here that the tabernacle and the temple were exempt from many rules and interdictions valid everywhere. For instance, the high priest in certain circumstances had to wear fabrics of wool and linen, which were otherwise generally forbidden; sacrifices were performed and musical instruments played during Shabbat and festivals, although these kinds of activities were not allowed in festive times and so on. So the cherubim on the ark were probably not seen as a transgression but rather as an exception. The problem with them is not a legal one, but a theological (and then a semiotic) one: what is the meaning of this exception to one of the most important rules of the relation regarding the transcendence in Jewish religion, how could it be explained?

The iconology of this cover and of the cherubim on its top is steady enough. ${ }^{17}$ Nevertheless, these figures were somehow changed in the more recent and famous sacred place of the Jewish religion, Solomon's Temple, built five centuries after the tabernacle (following the traditional chronology) and slightly but significantly different from its mobile prototype. There, we read, cherubim were made of different material (wood instead of gold) and in different dimensions (much bigger) and were also given a different position: ${ }^{18}$

In the inner sanctuary he made two cherubim of olivewood, each ten cubits high. He put the cherubim in the innermost part of the house; the wings of the cherubim were spread out so that a wing of one was touching the one wall, and a wing of the other cherub was touching the

16. The text tells us that all this things were exactly realized: "And he [Bazelel] made two cherubim of gold: of beaten work made he them, at the two ends of the ark-cover: one cherub at tone end, and one cherub at the other; of one piece with the ark-cover made he the cherubim at the two ends thereof. And the cherubim spread out their wings on high, screening the ark-cover with their wings, with their faces one to another; toward the ark-cover were the faces of the cherubim" (Exod. 37:7-9).

17. But it is difficult to figure out exactly the origin of it. Josephus witnesses that "nobody can tell, or even conjecture, what the shape of these cherubim was" (Antiquities 8.3.3).

18. Cherubim were also a widespread decoration in the tabernacle: on the veil between the Holy Place and the Holy of Holies, and on the hangings (Exod. 26:1 and 36:8); in Solomon's Temple they were engraved on the walls and on the doors (1 Kings 6:29-35), and on the bases of the huge basin called "molten sea" (1 Kings 9:29). They also occur in Ezekiel's visions of the temple of the future (Ezek. 41:18-25) and in his prophecy about Tyre (Ezek. 28:13-16). 
other wall; their other wings toward the center of the house were touching wing to wing. (1 Kings 6:23-27)

This last difference, underlined in the parallel 2 Chronicles version, ${ }^{19}$ is discussed and treated as fully meaningful by the Talmud:

How did they stand? R. Johanan and R. Eleazar [are in dispute on the matter]. One says: "They faced each other." And the other says: "Their faces were inward." But according to him who says that they faced each other, [it may be asked]: Is it not written, "And their faces were inward"? [This is] no difficulty: The former [was] at a time when Israel obeyed the will of the Omnipresent; the latter [was] at a time when Israel did not obey the will of the Omnipresent. ${ }^{20}$

This discussion is useful as a first clue about the cherubim's meaning and their utility. But before further exploring this direction, it may be useful to gather some more information about these enigmatic creatures. Their name occurs a number of other times in the Hebrew Bible and in the Jewish tradition, apart from the passages already quoted. They first appear as wardens in Genesis 3:23, placed by God "at the east of Eden, along with the revolving sword blade, to guard the path of the Tree of Life." ${ }^{21}$ The prophet Ezekiel describes the cherubim as a tetrad of living creatures, each having four faces - of a lion, an ox, an eagle, and a man - the stature and hands of a man, the feet of a calf, and four wings. Two of the wings extend upward, meeting above and sustaining the throne of God, while the other two reach downward and cover the creatures themselves. They never turn, but go "straight forward," as the wheels of the cherubic chariot; and they are full of eyes "like burning coals of fire" (Ezek. 1:5-28, 9:3, 10, 11:22). This aerial (and again terrifying) image of cher-

19. 2 Chron. 3:10-13: "For the Most Holy Place he made a pair of sculptured cherubim and overlaid them with gold. The total wingspan of the cherubim was twenty cubits. One wing of the first cherub was five cubits long and touched the temple wall, while its other wing, also five cubits long, touched the wing of the other cherub. Similarly one wing of the second cherub was five cubits long and touched the other temple wall, and its other wing, also five cubits long, touched the wing of the first cherub. The wings of these cherubim extended twenty cubits. They stood on their feet, facing the main hall."

20. Babylonian Talmud, Tractate Baba Bathra fol. 99a. Cf. the Zohar version (2:278a): "The Cherubs, when Israel was with merit, were face to face, entwined with each other, and when they lacked merit, they would turn their faces away from each other."

21. The most important exegete of Jewish tradition, Rashi (twelfth century) notes that "they are angels of destruction. Man is told that he must eventually die and is banished from paradise. He can only return to paradise after death, and before doing so, he must pass by these angels of purgatory (Bachya). The prophet must also pass these angels to approach the Tree of Life and obtain a vision. This is the significance of the cherubim on the Ark and those seen in Ezekiel's vision" (comment on Exod. 25:18). For other opinions, see Jewish Encyclopedia, s.v. "cherub," http://www.jewishencyclopedia.com/articles/4311-cherub. 
ubim allows us to understand the verse in 2 Samuel 22:11 (repeated in Ps. 18:11): "He rode on a cherub, and flew; He was seen upon the wings of the wind."22

There is an apparent variability in the shape and function of the cherubim, which could be explained by the fact that the word itself is a generic one and was probably imported into Hebrew from other languages and then interpreted in different ways. In general, the word cherub (pl. cherubim) is accounted by linguists as

a word borrowed from the Assyrian kirubu, from karâbu, "to be near"; hence, it means "near ones," "familiars," e.g., servants, bodyguards, courtiers. It was commonly used for heavenly spirits who closely surround the Majesty of God and pay Him intimate service. Hence, it came to mean as much as "Angelic Spirit." . . . The word has been brought into connection with the Egyptian Xefer by metathesis from Xeref=K-r-bh.) A similar metathesis and play upon sound undoubtedly exists between Kerub and Rakab, "to ride," and Merkeba, "chariot." In a Midrashic source a folk etymology is given according to which the singular form keruv means ke-ravya, "like a young child," hence the depiction in art and literature of the cherubim as baby angels. (Arendzen 1908) ${ }^{23}$

It is worth noting that in the very etymology of the word cherubim we find the same oxymoronic tension between transcendence and presence that is the subject of this article. This is true in general for "angels" (Hebrew malachim), which only in the late biblical books came "to mean the benevolent semidivine beings familiar from later mythology and art" (Coogan 2009). Before that they were meant as messengers charged with a single mission and immediately disappearing after that, or acting "aspects" or "interfaces" of the divinity, ${ }^{24}$ without personal identity or name. They can take on the role of pil-

22. Cf. 1 Sam. 4:4; 2 Sam. 6:2; 1 Chron. 13:6.

23. Cf. Talmud babli treatise Sukkah 5b: "What is the derivation of cherub? R. Abbahu said, 'Like a child', for in Babylon they call a child Rabia." "The Talmud makes a distinction between the face of a man and the face of a cherub, the latter being much smaller (Sukkah 5b)." Martina Corgnati pointed out to me that in Le nozze di Figaro, librettist Lorenzo da Ponte, who was a more or less a converted Jew, named his boy character who was very fond of women "Cherubino"; we will see why this characterization is meaningful. Another hypothesis is that the word comes from an Akkadian root meaning "to adore" (Montgomery and Gehman 2001, 155). The root seems also shared by Ethiopic mekrab 'sanctuary'.

24. This is the interpretation of Maimonides ([1186] 1904, 2.4), widely accepted in Jewish thought: "This leads Aristotle in turn to the demonstrated fact that God, glory and majesty to Him, does not do things by direct contact. God burns things by means of fire; fire is moved by the motion of the sphere; the sphere is moved by means of a disembodied intellect, these intellects being the 'angels which are near to Him,' through whose mediation the spheres [planets] move ... thus totally disembodied minds exist which emanate from God and are the intermediaries between God and all the bodies [objects] here in this world." 
grims (as in the stories of the visit to Moses and Sodom), wrestlers (with Jaakov), even fire (the burning bush), impersonal and invisible forces (the "angel of death" who kills the firstborn in Egypt), and so on. In general, their work is an act of communication, more or less interwoven with other kinds of symbolic or efficient actions. Their Hebrew name, malachim, in the Greek translation angelos, was inherited by Western languages with the meaning "messenger."

So we can consider the definition of angels more operational than essentialist, and the same can be said about with cherubim, which are generally treated as a category of angels. ${ }^{25}$ This operational character defines not only the "living" cherubim supporting the divine chariot or defending Eden, but also the "worked" or "made" cherubim on the curtains of the tabernacle, over the ark, or in the temple of Jerusalem. It is worth noting here that, in the biblical text and in the Talmudic discussions quoted before or elsewhere in the Jewish commentaries, these handmade cherubim are never defined as statues, or images or representations of angelic creatures, but simply as cherubim: "You shall make two cherubim of gold" (Exod. 25:18): "In the inner sanctuary he made two cherubim of olivewood" (1 Kings 6:23), and so on. Theoretically, this could be just a simplified description, as we refer to a Leonardo painting as "Mona Lisa" or note that "Michelangelo's Moses has horns." But one of the main features of Jewish hermeneutics is its carefully literal approach to every detail of the text; and this reference to the cherubim themselves instead of to their representations is too insisted on to be considered just meaningless. We have also to consider that different effects are attributed to these handmade cherubim, that is, they are given a sort of agency. As the "real" cherubim of Genesis and Ezekiel, but unlike other angels, the made ones too are not described as performing in the story, they are not active figures; but their presence matters, they are able (as "real" cherubim) to keep humans away from the Garden of Eden, or to mark the distance of the divine throne from the earth but also (as statues) to show the spiritual level of the people. Their function is a communicative one.

\section{Meetings}

The only function the handmade cherubim on the ark apparently performed was surrounding and in a certain sense allowing the focus of divine presence

25. For Maimonides, the cherubim represent a species of the angelic hosts (Jacobs 1995, quoted in http:// myjewishlearning.com/texts/Bible/Torah/Exodus/The_Tabernacle/Cherubim.shtml). 
in the tabernacle: "And when Moses went into the tent of meeting that $\mathrm{He}$ might speak with him, then he heard the Voice speaking unto him from above the ark-cover that was upon the ark of the testimony, from between the two cherubim; and He spoke unto him" (Num. 7:89). The "Voice" is said to speak to Moses "between the two cherubim." After the construction of the tabernacle, this is the standard setting described by the Torah for the divine presence. The cherubim are not speaking themselves, of course; they should not be mistaken for God. In this sense it is important that they are a couple: "there were two cherubim on the Ark because had there been only one it might have been confused with a representation of the One God." ${ }^{26}$ From a semiotic point of view, the presence of (generally) forbidden statues just around the divine presence marks and sets up a series of oppositions: concrete vs. immaterial, plural vs. unique, represented not-God vs. not-represented God. Considering the spatial disposition of the kapporet with the tools of plastic semiotics (Greimas 1984), it is easy to perceive that a main topological opposition shapes its signifying surface: the cherubim stay in the periphery enclosing and framing the divine voice in the middle. As often happens with this kind of configuration, there is a visual hierarchy: in the middle is the most important thing, and in the periphery is what is secondary, which plays just the role of witness and bystander. ${ }^{27}$ But in the center there is just nothing — or at least nothing visible. This way the plastic signifying opposition is able to convey a signified opposition: what is most important here, in the most important place of Jewish religion, and therefore what is most important in the whole world is not visible, has no shape, is not something material. The vacancy between the

26. Jacobs 1995, quoted in http://www.myjewishlearning.com/texts/Bible/Torah/Exodus/The_Tabernacle /Cherubim.shtml (see also a reference in Maimonides, Guide of the Perplexed 3.45). Jacobs (ibid.) continues: "The Jewish philosophers, in particular, tried to rationalize the subject. In Philo's discourse on the cherubim these represent two aspects of God, His goodness and His authority. . . . In Maimonides' scheme there are ten grades of angels, and the cherubim belong to the ninth degree. Angels are seen by Maimonides as the various spiritual forces God uses for the control of the universe. The angels adjacent to the Ark represent the operation of these spiritual forces in the revelation of the Torah and are a symbolic representation of the dogma that the Torah is from heaven. There were two cherubim on the Ark because had there been only one it might have been confused with a representation of the One God." Philo (On the Life of Moses 2.20.99, http://www.earlychristianwritings.com /yonge/book25.html) suggests the link with the two most important divine names of Judaism: "what is here represented under a figure are the two most ancient and supreme powers of the divine God, namely, his creative and his kingly power; and his creative power is called God; according to which he arranged, and created, and adorned this universe, and his kingly power is called Lord, by which he rules over the beings whom he has created, and governs them with justice and firmness"; cf. Patai 1978, 78. The Midrash Tadshe (called also Baraita de-Rabbi Pineh as b. Ya'ir) suggests another interpretation, not very far from Philo's one: the couple of cherubim could be a symbol for the two main divine attributes, justice and mercy.

27. (Represented) bystanders are considered by visual semiotics important devices for performing meaning effects, because they are able to stand for the audience and effectively involve it in their (represented) actions or attitudes. 
cherubim (in fact: the vacancy made perceptible by the cherubim presence) is the correct representation of Transcendence for the Jewish culture: this oxymoron is the really aniconic meaning and the function of the whole structure.

In fact, cherubim were not to be seen either. The only time Aaron and his successor high priests were admitted into the sacred space of the Holy of Holies was on the Day of Atonement; but also in that day "he shall place the incense upon the fire, before the Lord, so that the cloud of the incense shall envelope the ark cover that is over the [tablets of] Testimony, so that he shall not die" (Lev. 16:13). This means that, in order "not to die" (because "man shall not see Me and live" [Exod. 33:20]), even the high priest legally entering in the sacred space had to carefully make a smoke screen between himself and the ark so that he could not see the cherubim nor the space between them. ${ }^{28}$ But this invisibility was just a factual obligation. In principle (beyond the smoke) cherubim were visible, and the Divine Presence between them was just an absence framed by their presence. The opposition between the two invisibilities is not a factual one, it affects a semiotic modality. As happens for his name, the Tetragrammaton, which in the Jewish tradition should not be uttered and whose substitute should also not said outside of liturgical context (Volli 2012), this Presence too undergoes a double effacement, being invisible in principle and not to be seen in practice.

The most important thing is that there is no material source for the voice; this comes "between" the two messengers or witnesses, who are acting not so much as a communication bridge, because they are not making anything, but rather as a frame, a concrete condition for the communication to work. One could easily also note that the plural character of their presence is semiotically relevant. Looking at each other, as is prescribed, they are also looking at the Voice, or at least at its (absent) source; and, being two material objects in different positions, they necessarily look at it from different points of space, with different perspectives, as an audience always does while listening to someone. They materially introduce in the divine revelation that condition of plurality that is so important in the Jewish religion. ${ }^{29}$ This way, they

28. As Philo also witnesses: "All inside is unseen, except for the High Priest alone and indeed he, tough charged with the duty of entering once a year, gets no view of anything. For he takes with him a brazier full of lighted coal and incense and the great quantity of vapor . . . beclouds the sight"; Philo of Alexandria, De specialibus legibus 1.13.71, trans. Charles Duke Yonge, The Works of Philo: Complete and Unabridged (1854), http://www.earlychristianwritings.com/yonge/book27.html.

29. In the Jewish religion, the most important prayers and liturgical acts are valid only if performed at the presence of a minyan (a group of at least ten adult Jews). Following a less binding but widespread tradition, even the study of sacred texts should not be performed alone but in at least pairs. 
are somehow representing not a divine presence, but just the opposite, the Jewish people listening to God. The Voice speaking "between them" should, therefore, also be understood as a metaphor of "God dwelling in the midst [of the Israelites]" (Exod. 25:8). This hypothesis about cherubim as semiotic representatives (not representations) of the people can be supported with a rather odd page of the Babylonian Talmud (Tractate Baba Bathra 99a) I quoted before:

How did they [i.e., the cherubim in the Holy of Holies] stand? R. Johanan and R. Eleazar [are in dispute on the matter]. One says: "They faced each other" [Exod. 25:20]. And the other says: "Their faces were inward" [2 Chron. 3:13]. But according to him who says that they faced each other, [it may be asked]: is it not written, "And their faces were inward"? [This is] no difficulty: The former [was] at a time when Israel obeyed the will of the Omnipresent; the latter [was] at a time when Israel did not obey the will of the Omnipresent.

As is not unusual in the Talmud, this is an incidental discussion aiming to elucidate the biblical text and to remove a possible contradiction. The object is the cherubim's gaze: in the Exodus passage on the tabernacle (quoted fully above) they are described as "facing each other," while in the 2 Chronicles description of Solomon Temple they are directed "inward," that is, away from the viewers - who in fact happened to be just one, the high priest, the only one admitted in the sancta sanctorum but only during the service on the Day of Atonement (and forbidden to see them, as I showed before). What matters for us here is the explanation offered for this change: the cherubim looked at each other (and in the direction of the Voice) "at a time when Israel obeyed the will of the Omnipresent," that is, the mythical time of the Sinai and the Revelation; but they are said to look away (from each other and also from the intermediate space, where in fact there is no more Voice speaking) during the historical time when obedience to God and concord among the Jewish people have been lost.

In semiotic terms, we must note here a sort of semisymbolic link between the moral attitude of the Jewish people (as perceived by Talmudic rabbis) and the physical position attributed to the cherubim: a content opposition (obedience vs. disobedience; concord vs. discord) is expressed through an expression category (to look at each other vs. to look away). The direction of of the cherubim's gaze shows the tendencies of Jewish people's interest. So we should think again of the ark cherubim as being representative of the Jewish people 
(in semiotic terms, simulacra of the enunciatee) and not as representations of the divinity (signs of the utterer). They have a metacomunicative function, pointing at the state of the communication, expressing not its content but the relation.

There is another and more disquieting Talmudic remark about the cherubim which supports a similar identification of these representations with the Jewish People. This concerns the figures embroidered on the curtains protecting the sancta sanctorum and not the statues in it, but they are also cherubim and also prescribed by the Torah. As Jacobs put it, "A curious Talmudic legend has it that the cherubim in Solomon's Temple were in the form of male and female. When the Israelites came to the Temple on pilgrimage, the curtain in front of the ark was drawn aside and the cherubim were seen interlocked as if in sexual congress. This was said to be a miraculous indication that God's love for Israel resembles the love of man and woman." ${ }^{30}$

The Talmudic text $\left(\right.$ Yoma $_{\mathrm{b}}$ 54a) begins very simply. Speaking generally about the Day of Atonement (Yom Kippur) and its ritual in the temple, the discussion goes to the ark and from that to the cherubim. Then a quite odd statement is attributed to an important fourth-century rabbi, Kattina: "R. Kattina said: Whenever Israel came up [to Jerusalem] to the Festival, the curtain [the parrokhet that divided the space "holy" from the "holiest of the holy"] would be removed for them and the Cherubim were shown to them, whose bodies were inter-twisted with one another, and they would be thus addressed: Look! You are beloved before God as the love between man and woman."31

The discussion goes on about when this show could have taken place (the First or the Second Temple) and how the people could have seen the cherubim who were always hidden in the invisible space of the sancta sanctorum, following the rules of the Torah. There are two different explanations or rather comparisons, both referring to an erotic sphere. The first is more direct, as it pertains to the ark. As mentioned above, the Torah states that on the sides of the ark there must be always be two "staves," or poles, for its transfer, which should never be detached from it. 1 King 8:8 says that in Solomon's Temple they were only partly visible: "and the staves were so long that the ends of the staves were seen from the holy place before the cell; but they

30. Jacobs 1995, quoted from http://www.myjewishlearning.com/texts/Torah/Exodus/The_Tabernacle /Cherubim.shtml.

31. In relation to this union of the angelic creatures in the Holy of Holies, Elior further notes that "the grammatical relationship between the Hebrew words for the Holy of Holies—kodesh hakodashim — and for betrothal—kidushin — suggests an ancient common ground of heavenly and earthly union" (2004, 158). The translation of the text is from the Soncino English Babylonian Talmud, http://www.halakhah.com. 
were not seen from outside: and there they are unto this day." This means that they probably could be seen only from a certain position and not "from outside" (hahoutza).

But the Talmudic interpretation is more complex (Yoma $\left.{ }_{\mathrm{b}} 54 \mathrm{a}\right)$ :

R. Judah contrasted the following passages: And the ends of the staves were seen and it is written but they could not be seen from outsidehow is that possible?-They could be observed, but not actually seen. Thus was it also taught: "And the ends of the staves were seen." One might have assumed that they did not protrude from their place. To teach us [the fact] Scripture says: "And the staves were so long." One might assume that they tore the curtain and showed forth; to teach us [the fact] Scripture says: "They could not be seen without." How then? They pressed forth and protruded as the two breasts of a woman, as it is said: My beloved is unto me as a bag of myrrh, that lieth betwixt my breasts.

This interpretation, apart from its erotic flavor, elaborates a dialectic between visible and not-visible (nirin veen nirin, as analyzed by Ouaknine [1986] 1998). It can be usefully compared with a semiotic understanding of images because their attempted effect is always the presence of an absence, the visibility of something that could not be seen because far or imaginary, the opening of a virtual otherness. But this metaphor of the staves should be also approached from the perspective of the communicative position of transcendence, whose unworldliness is the very condition for the meaning of its traces. This last side of the oxymoron is underlined in a beautiful analysis of this passage by Ouaknine ([1986] 1998, 265-334). But we have also to remember here the explanation of Lévinas quoted above about the poles as symbol of the Law mobility.

The second explanation, on the same oxymoronic order, is taken from the family life (Yoma $\mathrm{b}$ 54a): "R. Nahman answered: That may be compared to a bride: As long as she is in her father's house, she is reserved in regard to her husband, but when she comes to her father-in-law's house, she is no more so reserved in regard to him." The most important point in this comment is a triple comparison: the loves between the cherubim, between man and women, and between God and the Jewish people are somehow similar. The comparison between marital love and the relation between Israel and God is a very persistent motif in the prophetical writing and in one important Jewish mystical tradition beginning with a Talmudic statement by the great Rabbi Akiva: 
"When husband and wife are worthy, the Shechinah [divine presence] abides with them; when they are not worthy fire consumes them" (Sotah 17a). From this starting point, the equivalence of marital life with the no more active temple as a residence for the Divine Presence begins an important mystical path, whose later rich development is explored by Idel (2005). The link with cherubim is less known but was also always active (Orlov 2012, 138 n. 69):

In later Jewish mysticism the imagery of the Cherubim in the Holy of Holies was interpreted as the conjugal union between male and female. Thus, in Zohar III.59b the following tradition can be found: "R. Simeon was on the point of going to visit R. Pinchas ben Jair, along with his son R. Eleazar. When he saw them he exclaimed: 'A song of ascents; Behold how good and how pleasant it is for brethren to dwell together in unity"” (Ps. CXXXIII, 1). 'The expression "in unity," he said, refers to the Cherubim. When their faces were turned to one another, it was well with the world- "how good and how pleasant," but when the male turned his face from the female, it was ill with the world. Now, too, I see that you are come because the male is not abiding with the female. If you have come only for this, return, because I see that on this day face will once more be turned to face."' [Sperling and Simon 1933, 5:41]. Another passage from the Zohar III.59a also tells about the conjugal union of the cherubim: "Then the priest used to hear their voice in the sanctuary, and he put the incense in its place with all devotion in order that all might be blessed. R. Jose said: The word 'equity' (mesharim, lit. equities) in the above quoted verse indicates that the cherubim were male and female. R. Isaac said: From this we learn that where there is no union of male and female men are not worthy to behold the divine presence" (41).

Hierogamic rituals were widely diffused in Middle East for all the biblical period, but the Hebrew religion was always self-defined in a fierce polemic with these practices and tried to eradicate them the hard way, as shown by the divine endorsement of the double killing performed by Pinhas against a couple involved in sexual activity with idolatrous meaning (Num. 25:1-5, $31: 16)$.

This attitude should make the presence of the loving cherubim in the temple very strange, a serious twofold transgression: not only are there statues against all Jewish aniconic spirit in the Hebrew religion's most sacred 
place, but these images have a scandalously sexual appearance. In fact, the same Talmudic text that hands down this unsetting tradition expresses worry for it $\left(\right.$ Yoma $_{b}$ 54b):

And it is written also: According to the space of each, with loyoth [wreaths round about]. What does "according to the space of each with loyoth" mean? Rabbah son of R. Shilah said: even as a man embracing his companion. Resh Lakish said: When the heathens entered the Temple and saw the Cherubim whose bodies were intertwisted with one another, they carried them out and said: These Israelites, whose blessing is a blessing, and whose curse is a curse, occupy themselves with such things! And immediately they despised them, as it is said: All that honored her, despised her, because they have seen her nakedness [Lam. 1:8]. ${ }^{32}$

The same idea of the cherubim as something shameful in the eyes of foreigner, hence a secret, is found in a very old midrash from the mishnaic time: "When the sins caused that the gentiles should enter Jerusalem, Ammonites and Moabites came together with them, and they entered the House of the Holy of Holies, and found there the two Cherubiym, and they took them and put them in a cage and went around with them in all the streets of Jerusalem and said, 'You used to say that this nation was not serving idols. Now you see what we have found and what they were worshipping'" (Lamentations rabbah, proem 9). It is perhaps significant in this connection that while the liturgy contains several references to other kind of angels - for example, seraphimthere are only a few references to the cherubim in the liturgy, as far as I know. ${ }^{33}$ Even if metaphoric, as I maintain, this image is both widely spread and disquieting.

\section{Conclusion}

The Talmudic and the midrashic text, both written centuries after the destruction of the Temple, tell us about social memory and do not necessarily

32. Loyoth is connected with the root signifying "attach," hence "companions" (cf. English "conjugal"); see http://juchre.org/talmud/yoma/yoma3.htm.

33. Cherubim are occasionally named in a psalm — as with Psalm 99, which is used in sabbatical liturgyand appear in a very hypothetical prevision in Mishnah Berakhot 49b, concerning the "grace" prayer said after meals (Birkhat hamazon): "If there are three [persons sitting at a table], he [the one saying grace] says, "let us bless'. . . . if there are ten, he says, let us bless our God'; . . if there are a hundred he says, 'let us bless the Lord our God'; . . . if there are a thousand he says 'let us bless the Lord our God, the God of Israel'; . . if there are ten thousand he says, "let us bless the Lord our God, the god of Israel, the God of hosts, who dwells among the cherubim." There is no damnatio memoriae for them. But their presence is clearly minor in front of seraphim (often summoned as the first performer of the Trisagion and quoted in the Yotzer benediction before the Shema) and also of the lesser-known Ofanim and Chaiot coming from the book of Ezekiel. 
give us the historical truth. But social memory is the one of the most powerful social devices for preserving identity (Halbwachs 1925; Assman 1992), so their narrations are very meaningful. In fact, the specific contempt by foreign people they fear - the one about the iconic and sexual side of cherubim - did not appear: many others reasons for hate against Jews were proposed, but not this one. The "heathen" did not "despise them" for an alleged idolatry, that is for having too broad a faith-just the contrary, they "despised them" for their refusal to belief in a Messiah and a prophet, that is for having "too narrow" a faith. So we have to consider their concerns rather as a sign of internal discomfort: "The Cherubim are our nakedness; a vulnerable moment-a moment that questions the very foundation of normative Judaism, where God has no face and no name; a crack in the holy of holies. Perhaps, the sacred demands inconsistency and ambiguity even if might embarrass." ${ }^{34}$

In different framework, Jacques Lacan and Jurij Lotman have noted that every system of meaning must have its own "catastrophic" or "blind" point, where the system is grounded and at the same time finds its limit. We cannot relate the features of the cherubim images (or their memory) to any specific time of the history of Jewish society, because this iconological and narrative motif is found in the Jewish texts from the Exodus (traditionally dated to the fourteenth century; in a more philological way, from the source $\mathrm{P}$, which usually is dated "before the Jerusalem conquest by the Babylonians in 587"35) through the prophet Ezekiel (seventh century BCE), the later book of Kings (fifth century BCE), to the Mishnah and first Midrash (third century CE), the Talmud ( sixth century), the Zohar (thirteenth century), and up to the Chassidic movement (eighteenth century). So it should be considered as a permanent feature of the Jewish world image and, in a more specific way, as a very peculiar way of facing the presence of the transcendence, if not its representation: a very complex and critical case of religious semiotics in action. And a critical "blind" point for the Jewish understanding of the Divine and its relation with it.

The whole history of the cherubim images (and then of the memory of these images) in the Jewish culture has yet to be written. But from a semiotic point of view, this paper can conclude that they are not representations of any deity, a form of idolatry. ${ }^{36}$ They are not addressed, not worshiped, not

34. Anna Batler, http://www.gatherthejews.com/2011/02/torah-portion-who-are-the-cherubim-kerubim -or-the-winged-statutes-atop-the-holy-ark/.

35. Friedman 1987, chap. 11; cf. also the appendix for the identification of $P$.

36. It is useful to recall here Maimonides's argument (Guide to the Perplexed 3.45): "If there had been only one figure of a cherub, the people would have been misled and would have mistaken it for God's image which 
supposed to act. No story, no action is narrated about the creatures they should represent - if they were representative texts. There is no such a thing as a cherubim myth. For sure they cannot be considered as an image of God, as someone interprets another famous image in the Jewish story, the golden calf.

Cherubim are only relational signs, marking the communication between transcendence and Jewish people. With a sword at the border of Eden, after Adam and Eve expulsion, they allude to the removal of the direct link with God; with wings and wheels in Ezekiel, they hint to the distance from the Divinity; looking to where the "Voice" speaks, they witness the possibility of hearing God's will from different points of view and underline with their materiality the unworldliness and immateriality; approaching each other to a love act they show a possible condition of harmony and fertility in the relations inside the Jewish people and between the people and God; looking away from each other, they signal the opposite state of disagreement and segregation.

As every angel is in Jewish thought, they are conceived as communication devices: they don't re-present transcendence but present, as a sort of indexical/ iconic signs, ${ }^{37}$ the modality of the relation with it. This is a very intimate and actually secret presentation, which is very fragile when exposed to an outsider glance, because it works also as a sort of mirror, reflecting the human condition and its weakness in front of God. Cherubim are not transcendence signs, but a metasign of its possibility. That is why an aniconic culture such as the Jewish tradition hides it in the very center of its symbolic system.

\section{References}

Abarbanel, Yitzhak. (1504) 2012. Sefer Pirush haTorah leAbarbanel. New York: Hebrew Books.

Appadurai, Arjun, ed. 1986. The Social Life of Things. Cambridge: Cambridge University Press.

Apple, Raymond. 1995. Oz Torah. Sidney: Grand Synagogue.

Arendzen, John. 1908. Entry on "Cherubim." In The Catholic Encyclopedia. New York: Appleton.

Assman, Jan, 1992. Das kulturelle Gedaechnis. Munich: Beck.

Belting, Hans. 2005. Das Echte Bild: Bildfragen als Glaubenfragen. Munich: Beck.

was to be worshipped, in the fashion of the heathen; or they might have assumed that the angel (represented by the figure) was also a deity, and would thus have adopted a dualism" (Maimonides 1904).

37. The combination of indexical and iconic is much more frequently studied: think about computer pointers, figurative barometers, and so on. 
Bettetini, Maria. 2006. Contro le immagini: Le radici dell'iconoclastia. Rome: Laterza.

Coogan, Michael D. 2009. A Brief Introduction to the Old Testament. Oxford: Oxford University Press.

Dorfles, Gillo. 1988. Il feticcio quotidiano. Milan: Feltrinelli.

Elior, Rachel. 2004. The Three Temples: On the Emergence of Jewish Mysticism. Portland, OR: Littman Library of Jewish Civilization.

Friedman, Richard Eliott. 1987. Who Wrote the Bible. New York: Summit Books.

Geary, Patrick. 1986. "Sacred Commodities: The Circulation of Medieval Relics.” In The Social Life of Things, ed. Arjun Appadurai, 169-91. Cambridge: Cambridge University Press.

Goody, Jack. 1997. Representations and Contradictions: Ambivalence towards Images, Theatre, Fiction, Relics, and Sexuality. London: Blackwell.

Greimas, Algeidras. 1984. “Sémiotique figurative et sémiotique plastique.” Actes Sémiotiques: Documents 60 (4): 30-43.

Halbwachs, Maurice. 1925. Les Cadres sociaux de la mémoire. Paris: Alcan.

Idel, Moshe. 2005. Kabbalah and Eros. New Haven, CT: Yale University Press.

Jacobs, Louis. 1995. The Jewish Religion: A Companion. Oxford: Oxford University Press.

Kereny, Karl. 1962. “Agalma, Eikon, Eidolon.” Archivio di Filosofia 1 (2): 161-71.

Kurulyk, Ewa. 1991. Veronica and Her Cloth: History, Symbolism, and Structure of a "True" Image. Oxford: Blackwell.

Le Goff, Jacques. 1985. L’imaginaire médiéval. Paris: Gallimard.

Lévinas, Emmanuel. (1982) 1994. Nine Talmudic Readings. Bloomington: Indiana University Press. Originally published as L'Au-delà $d u$ verset: Lectures et discours talmudiques. Paris: Éditions du Minuit.

- 1984. Transcendance et Intelligibilité. Geneva: Labor et Fides.

-1995. Altérité et transcendance. Montpellier: Fata Morgana.

Maimonides, Mose. (1186) 1904. A Guide for the Perplexed. New York: Dutton.

Montgomery, James A., and Henry Snyder Gehman. 2001. Kings I and II: International Critical Commentary. London: Clark.

Orlov, Andrei A. 2012. Dark Mirrors: Azazel and Satanael in Early Jewish Demonology. Albany, NY: SUNY Press.

Ouaknin, Marc-Alain. (1986) 1998. The Burnt Book: Reading the Talmud. Princeton, NJ: Princeton University Press. Originally published as Le livre brulé. Paris: Lieu commun.

Patai, Raphael. 1978. The Hebrew Goddess. Detroit: Wayne State University Press.

Russo, Luigi, ed. 1997. Vedere l'invisibile: Nicea e lo statuto dell'immagine. Palermo: Aesthetica.

Sperling, H., and M. Simon, ed. and trans. 1933. The Zohar. 5 vols. London: Soncino.

Veyne, Paul. 1983. Les Grecs ont-ils cru à leurs mythes? Essai sur l'imagination constituante. Paris: Éditions du Seuil.

Volli, Ugo. 1997. Fascino. Milan: Feltrinelli.

—. 2009. “¿Qué cosa es un libro para el Libro de los libros?” Tópicos del seminario 22:75-103.

- 2012. Domande alla Torah. Palermo: L'Epos.

- 2014. "L'ineffabile e l'apparizione." Lexia, no. 15-16, forthcoming.

Warburg. Aby. 2003. Der Bilderatlas Mnemosyne. Berlin: Warnke. 